\title{
DRUG UTILISATION REVIEW IN POSTOPERATIVEPATIENTS IN OBSTETRICS-GYNAECOLOGY AND SURGICAL GASTROENTEROLOGY DEPARTMENTS-A RETROSPECTVE STUDY
}

\author{
MADHURI DEVI THADIBOINA*, SETTIPALLI BALA ADITHYA, KANNA VADIVEL \\ Southern Institute of Medical sciences, Department of pharmacy, Mangaldas nagar, Guntur, Andhra Pradesh, India \\ Email: madhuriphamrd25@gmail.com
}

Received: 09 Jul 2018 Revised and Accepted: 17 Sep 2018

\begin{abstract}
Objective: The main objectives of our study include classification, analysis and assessment of all the post-operative drugs present of our study.

Methods: The current project being a retrospective drug utilization review 50 prescriptions from the post-surgical wards of obstetrics-gynaecology and surgical gastroenterology departments were collected and analysed.

Results: All the data collected was classified, analysed and assessed based on the various factors and the results were people between the age group of 41-50 have undergone more number of surgeries $22 \%$. Only $32 \%$ of all the prescriptions were found to have poly pharmacy, classification of all the prescribed drugs shows that the anti biotics were prescribed in the maximum number i.e. 152doses. Parenteral type of formulation was given in high number of doses up to 506 doses. Defined daily doses of all the W. H. O essential drug list medications were done. W. H. 0 prescribing
\end{abstract} indicators for all the drugs in our study was also calculated.

Conclusion: Our study concludes that the antibiotic drug therapy was used as prophylaxis to prevent the bacterial infection.

Keywords: Retrospective study, Drug utilisation review, Poly pharmacy, Defined daily doses, Prescribing indicators, Prophylaxis

(C) 2018 The Authors. Published by Innovare Academic Sciences Pvt Ltd. This is an open access article under the CC BY license (http://creativecommons.org/licenses/by/4.0/) DOI: http://dx.doi.org/10.22159/ijpps.2018v10i10.28387

\section{INTRODUCTION}

Drug utilization review (DUR) is an authorized, organized, ongoing study of prescribing, dispensing and use of different types of medication. DUR study involves a complete study of the prescriptions and the related drug data. Usually, DUR study goes as three different methods as prospective, concurrent and retrospective; the prospective method-This method involves the evaluation of a prescription and the medications before the drugs are dispensed. Concurrent-This is an ongoing study, in this the prescriptions are analyzed and monitored during the course of the treatment. Retrospective-In this method, the prescriptions are analysed after the drugs are dispensed [1].

DUR study helps in managing health care systems to assess, explain, understand and improve the prescribing, administration and use of various drugs. Various sectors of healthcare management like health care providers consider the DUR program extremely valuable as the results are used to boost the more efficient use of drugs [2]. Clinical pharmacists contribute to a major role in DUR studies because of their proficiency in the field of drug therapy. DUR studies can enhance the quality of care not only for patients but also for the entire population by optimizing the drug therapy by preventing the use of inappropriate drugs, taking measures to minimize or avoid adverse drug reactions thus by improving the drug effectiveness $[3,4]$.

Various synonyms considered for DUR include Medication use management, medication use evaluation (MUE) and drug use evaluation (DUE) [5]. Since the enforcement of the OBRA 90 (Omnibus Budget Reconciliation Act of 1990), various states have enacted their own regulations which require pharmacists to collect medication reviews from all the outpatients. Another similar official order was introduced in the Medicare prescription drug improvement and modernization act of 2003 as medication therapy management (MTM). MTM provides appropriate drug plan to sponsors by offering a review and appropriate interventions on the drugs prescribed [6,7].

Our present study primarily focuses on the DUR in the postoperative patients in the departments of the surgical gastroenterology and the gynaecology departments respectively. Our team has come forward with the aim to conduct a drug utilization review in postoperative patients in the departments of surgical gastroenterology, obstetrics, and gynaecology. We have chosen all the postoperative drugs in the two departments.

The main objectives of our study include classifying all the postoperative drugs into their respective categories based on their classification, route of administration and type of formulation. In addition our study includes analysing the pattern of drug use among the patients based on the age and gender of the patients, polypharmacy assessment, calculation of the Defined daily doses of the various drugs as per the World Health Organisation (W. H. O) guidelines, calculation of the $\mathrm{W}$. $\mathrm{H}$. O prescribing indicators of the respected prescribed drugs as the objectives.

\section{MATERIALS AND METHODS}

\section{Methods}

The study was conducted at a territory care hospital in the departments of the surgical gastroenterology, Obstetrics and gynaecology, after the informed consent from the volunteer respondents and a valid ethical clearance form from Human ethical committee with the reference number IHEC/SIMS/2017/011.

The retrospective drug utilization review includes volunteer post-operative in-patients of both the genders from the surgical gastroenterology, obstetrics and gynaecology departments from 2016-2018. Pregnant women were excluded from our study. 


\section{RESULTS}

Table 1: Age and gender distribution

\begin{tabular}{lllll}
\hline Age & Male & Female & Total & Percentage \\
\hline $10-20$ & 3 & 3 & 6 & $12 \%$ \\
$21-30$ & 2 & 7 & 9 & $18 \%$ \\
$31-40$ & 3 & 7 & 10 & $20 \%$ \\
$41-50$ & 2 & 9 & 11 & $22 \%$ \\
$51-60$ & 2 & 4 & 6 & $12 \%$ \\
$>60$ & 4 & 4 & 8 & $16 \%$ \\
\hline
\end{tabular}

Table 2: Polypharmacy assessment

\begin{tabular}{|c|c|c|c|c|}
\hline No. of drugs prescribed & Male & Female & Total & Percentage \\
\hline$<5$ & 11 & 23 & 34 & $68 \%$ \\
\hline$>5$ & 6 & 10 & 16 & $32 \%$ \\
\hline
\end{tabular}

Table 3: Distribution of medication in patients

\begin{tabular}{|c|c|c|c|}
\hline S. No. & Distribution of drugs & No. of doses & Percentages \\
\hline 1. & Antibiotics & 152 & $18.26 \%$ \\
\hline 2. & Anti hypertensives & 30 & $3.60 \%$ \\
\hline 3. & Antacids & 139 & $16.70 \%$ \\
\hline 4. & Anti hyperlipidemics & 1 & $0.12 \%$ \\
\hline 5. & Anti protozoals & 127 & $15.26 \%$ \\
\hline 6. & Analgesics & 105 & $12.62 \%$ \\
\hline 7. & Anti-emetics & 92 & $11.05 \%$ \\
\hline 8. & Vitamin supplements & 1 & $0.12 \%$ \\
\hline 9. & Anti-fibrinolytics & 3 & $0.36 \%$ \\
\hline 10. & Anti-anxiety & 2 & $0.24 \%$ \\
\hline 11. & Thyroid drugs & 6 & $0.72 \%$ \\
\hline 12. & Laxatives & 15 & $1.80 \%$ \\
\hline 13. & Iron supplements & 14 & $1.68 \%$ \\
\hline 14. & Sympathomimetics & 3 & $0.36 \%$ \\
\hline 15. & Corticosteroids & 32 & $3.84 \%$ \\
\hline 16. & Local Anesthetics & 6 & $0.72 \%$ \\
\hline 17. & Anti-coagulants & 12 & $1.44 \%$ \\
\hline 18. & Anti-histamines & 6 & $0.72 \%$ \\
\hline 19. & Muscle relaxants & 4 & $0.48 \%$ \\
\hline 20. & Acetyl cholinesterase inhibitors & 3 & $0.36 \%$ \\
\hline 21. & Hormones & 6 & $0.72 \%$ \\
\hline 22. & Broncho dilators & 3 & $0.36 \%$ \\
\hline 23. & Anti-psychotics & 4 & $0.48 \%$ \\
\hline 24. & Anti-pyretics & 31 & $3.72 \%$ \\
\hline 25. & Enzymes & 5 & $0.60 \%$ \\
\hline 26. & Anti-epileptics & 4 & $0.48 \%$ \\
\hline 27. & Beta 2 receptor agonist & 26 & $3.125 \%$ \\
\hline
\end{tabular}

Table 4: Distribution of formulation

\begin{tabular}{lll}
\hline Type of formulation & No. of doses & Percentage \\
\hline Parenteral & 506 & $63.01 \%$ \\
Oral & 234 & $29.14 \%$ \\
Nebulizer & 58 & $7.22 \%$ \\
Suppository & 2 & $0.24 \%$ \\
Topical & 3 & $0.37 \%$ \\
\hline
\end{tabular}

Table 5: Defined daily doses of various drugs

\begin{tabular}{lllll}
\hline S. No. & ATC code & Drug name & DDD & Route of administration \\
\hline 1. & C01CA07 & Dobutamine & $0.5 \mathrm{~g}$ & Parenteral \\
Oral & Parenteral \\
& A02BC02 & Pantoprazole & $40 \mathrm{mg}$ & Oral \\
3. & A02BC04 & Rabeprazole & $20 \mathrm{mg}$ & Oral \\
4. & A02BC01 & Omeprazole & $20 \mathrm{mg}$ & Parenteral \\
& & & Parenteral \\
5. & J01XD01 & Metronidazole & Parenteral & Oral \\
6. & J01DD04 & Ceftriaxone & $2 \mathrm{~g}$ & Parenteral \\
7. & T02AX02 & & $0.3 \mathrm{~g}$ & Rectal \\
& & &
\end{tabular}




\begin{tabular}{|c|c|c|c|c|}
\hline 8. & A04AA01 & Ondansetron & $16 \mathrm{mg}$ & $\begin{array}{l}\text { Oral } \\
\text { Rectal } \\
\text { Parenteral }\end{array}$ \\
\hline 9. & B01AB01 & Heparin & $10 \mathrm{TU}$ & Parenteral \\
\hline 10. & B01AB04 & Dalteparin & $2.5 \mathrm{TU}$ & Parenteral \\
\hline 11. & J01MA01 & Ofloxacin & $0.4 \mathrm{~g}$ & $\begin{array}{l}\text { Oral } \\
\text { Parenteral }\end{array}$ \\
\hline 12. & J01MA02 & Ceprofloxacin & $\begin{array}{l}1 \mathrm{~g} \\
0.5 \mathrm{~g}\end{array}$ & $\begin{array}{l}\text { Oral } \\
\text { Parenteral }\end{array}$ \\
\hline 13. & J01MA06 & Norfloxacin & $0.8 \mathrm{~g}$ & Oral \\
\hline 14. & J01MA12 & Levofloxacin & $0.5 \mathrm{~g}$ & $\begin{array}{l}\text { Oral } \\
\text { Parenteral }\end{array}$ \\
\hline 15. & C09CA07 & Telmisartan & $40 \mathrm{mg}$ & Oral \\
\hline 16. & C08CA01 & Amlodipine & $5 \mathrm{mg}$ & Oral \\
\hline 17. & J01DD13 & Cefpodoxime & $0.4 \mathrm{~g}$ & Oral \\
\hline 18. & N02BB01 & Paracetmol & $3 g$ & Oral \\
\hline 19. & N06AB05 & Paroxetine & $20 \mathrm{mg}$ & Oral \\
\hline 20. & N03AE01 & Clonazepam & $8 \mathrm{mg}$ & $\begin{array}{l}\text { Oral } \\
\text { Parenteral }\end{array}$ \\
\hline 21. & M01AB16 & Aceclofenac & $0.2 \mathrm{~g}$ & Oral \\
\hline 22. & M01AB05 & Diclofenac & $0.1 \mathrm{~g}$ & $\begin{array}{l}\text { Oral } \\
\text { Parenteral } \\
\text { Rectal }\end{array}$ \\
\hline 23. & N02AB03 & Fentanyl & $0.6 \mathrm{mg}$ & $\begin{array}{l}\text { Nasal } \\
\text { Sub lingual } \\
\text { Trans dermal }\end{array}$ \\
\hline 24. & С01BB01 & Lidocaine & $3 g$ & Parenteral \\
\hline 25. & B02AA02 & Tranexamic acid & $2 \mathrm{~g}$ & $\begin{array}{l}\text { Oral } \\
\text { Parenteral }\end{array}$ \\
\hline 26. & G03AC01 & Norethistherone & $2.5 \mathrm{~g}$ & Parenteral \\
\hline 27. & A03FA01 & Metoclopramide & $30 \mathrm{mg}$ & $\begin{array}{l}\text { Oral } \\
\text { Parenteral } \\
\text { Rectal }\end{array}$ \\
\hline 28. & B03АA07 & Ferrous Sulphate & $0.2 \mathrm{~g}$ & Oral \\
\hline 29. & В03ВB01 & Folic acid & $0.4 \mathrm{mg}$ & Oral \\
\hline 30. & G03DA04 & Progesterone & $\begin{array}{l}0.3 \mathrm{~g} \\
5 \mathrm{mg} \\
0.2 \mathrm{~g} \\
90 \mathrm{mg}\end{array}$ & $\begin{array}{l}\text { Oral } \\
\text { Parenteral } \\
\text { Rectal } \\
\text { Vaoinal }\end{array}$ \\
\hline 31. & G03DA03 & $\begin{array}{l}\text { Hydroxy } \\
\text { progesterone }\end{array}$ & $10 \mathrm{mg}$ & Parenteral \\
\hline 32. & A03FA03 & Domperidone & $\begin{array}{l}0.12 \mathrm{~g} \\
30 \mathrm{mg} \\
30 \mathrm{mg}\end{array}$ & $\begin{array}{l}\text { Rectal } \\
\text { Parenteral } \\
\text { Oral }\end{array}$ \\
\hline 33. & J01XX08 & Linezolid & $1.2 \mathrm{~g}$ & $\begin{array}{l}\text { Oral } \\
\text { Parenteral }\end{array}$ \\
\hline 34. & C07AB02 & Metoprolol & $0.15 \mathrm{~g}$ & $\begin{array}{l}\text { Oral } \\
\text { Parenteral }\end{array}$ \\
\hline 35. & C03CA01 & Furosemide & $40 \mathrm{mg}$ & $\begin{array}{l}\text { Parenteral } \\
\text { Oral }\end{array}$ \\
\hline 36. & C07AG01 & Labetalol & $0.6 \mathrm{~g}$ & $\begin{array}{l}\text { Oral } \\
\text { Parenteral }\end{array}$ \\
\hline 37. & J01DD13 & Cefpodoxime & $0.4 \mathrm{~g}$ & Oral \\
\hline 38. & H02АВ09 & Hydrocortisone & $30 \mathrm{mg}$ & $\begin{array}{l}\text { Oral } \\
\text { Parenteral }\end{array}$ \\
\hline 39. & N05AL07 & Levosulpiride & $0.4 \mathrm{~g}$ & Oral \\
\hline 40. & C08CA14 & Clinidipine & $10 \mathrm{mg}$ & Oral \\
\hline 41. & H03AA01 & Levothyroxine sodium & $0.15 \mathrm{mg}$ & $\begin{array}{l}\text { Oral } \\
\text { Parenteral }\end{array}$ \\
\hline 42. & R01AD05 & Budesonide & $0.2 \mathrm{mg}$ & Nasal \\
\hline 43. & R03AC02 & Salbutamol & $0.8 \mathrm{mg}$ & $\begin{array}{l}\text { Inhalation Aerosol } \\
\text { Inhalation Powder } \\
\text { Inhalation Solution }\end{array}$ \\
\hline 44. & N02AJ13 & Tramadol+Paracetamol & $\begin{array}{l}4 \text { UD } \\
\text { (4Tabs) }\end{array}$ & Oral \\
\hline
\end{tabular}

Table 6: W. H. O. prescribing indicators

\begin{tabular}{lll}
\hline S. No. & Prescribing indicators & Number \\
\hline 1. & Total no. of prescriptions analysed & 50 \\
2. & Total no. of drugs prescribed & 212 \\
3. & Average no. of drugs per prescription & 4 \\
4. & Drug prescription by generic names & 185 \\
5. & Drugs prescribed from Essential Drug List (EDL) & 48 \\
6. & Total no. of prescriptions with Antibiotics & 49 \\
7. & Drugs prescribed by brand names & 27 \\
8. & Total no. of doses prescribed & 803 \\
\hline
\end{tabular}




\section{DISCUSSION}

A comprehensive study of all the 50 prescriptions was done for the drug classification according to their categories, route of administration, age, and sex distribution. Polypharmacy assessment and defined daily doses calculation was also conducted for all the postoperative drugs in our study, finally the W. H. O prescribing parameters were also done. The results showed that the highest count of postoperative patients between the ages of 41-50 y was 11 . Followed by the second highest postoperative 10 patients between the ages of 31-40. 9 postoperative patients were within the age group of 21-30. Elderly postoperative patients of the age group above $60 \mathrm{y}$ were 8 . And the postoperative patients of the two categories between the age group of 10-20 and 51-60 were in the same count of 6 respectively. The gender and age distribution results show that the total number of females to undergo surgery were more when compared to males. More than 5 drugs per prescription on a single day was considered as polypharmacy. Out of the 50 prescriptions analysed there were 16 prescriptions reported as polypharmacy. All the drugs in the prescriptions were classified based on their class. In our study a total of 27 classes of drugs were analysed and they were classified according to the number of doses of each drug for duration of $3 \mathrm{~d}$. The highest count of doses being the anti biotics with 152 doses, making a percentage of $18.26 \%$, antacids were dispensed in 139 doses making 61.70\%, anti hypertensives being 30 doses and $3.60 \%$, anti hyperlipidemics were given a single dose making a $0.12 \%$, anti protozoals were given in 127 doses making a percentage of $15.26 \%$, analgesics were given in 105 doses and a percentage of $12.62 \%$, anti-emetics were given in 92 doses making a percentage of $11.05 \%$, vitamin supplements were given at one dose making $0.12 \%$, anti-fibrinolytics, acetyl cholinesterase inhibitors and broncho dilators were given in 3 doses making a percentage of $0.36 \%$,anti-anxiety medications were given in 2 doses making a total of $0.24 \%$, thyroid medications were given in 6 doses making a percentage of $0.72 \%$, laxatives were prescribed in 15 doses which make $1.80 \%$, iron supplements were given in 14 doses making a percentage of $1.68 \%$, corticosteroid medications were given in 32 doses making a percentage of 3.84\%, there were 6 local anaesthetics given making a percentage of $0.72 \%, 12$ anti-coagulants doses make a percentage of $1.44 \%, 6$ anti-histamine doses make a percentage of $0.72 \%$, muscle relaxants were given as 4 doses making $0.48 \%, 0.72 \%$ of hormones were prescribed under 6 doses, 4 antipsychotic drugs were prescribed under $0.48 \%$ of all the drugs, 31 doses of anti pyretics drugs were prescribed making 3.72\%, 5 doses of enzymes were prescribed making a percentage of $0.60 \%, 4$ doses of anti-epileptic drugs were prescribed in $0.48 \%, 26$ doses of beta 2 receptor agonists fall under $3.125 \%$ of all doses prescribed[8,9]. All the drugs in the 50 prescriptions were analysed and distributed in to different types of the formulations parenterals were given in 506 doses making $63.01 \%$, oral formulations were given in 234 doses making 29.14\%, nebulizers were given in 58 doses making $7.22 \%$, suppositories were given in 2 doses making $0.24 \%$ of all the formulations given, topical drugs were given in 3 doses making a percentage of $0.37 \%$. Defined daily doses (D. D. D) of the individual drug per day was calculated according to the W. H. O guidelines, the anatomical therapeutic chemical (ATC) classification system and the route of administration of the respective drugs were mentioned for individual drug. The DDD of the drugs were dobutamine $0.5 \mathrm{~g}$, pantoprazole $40 \mathrm{mg}$, rabeprazole $20 \mathrm{mg}$, omeprazole $20 \mathrm{mg}$, metronidazole $1.5 \mathrm{mg}$, ceftriaxone $2 \mathrm{~g}$, tramadol $0.3 \mathrm{~g}$, ondansetron $16 \mathrm{mg}$, heparin $10 \mathrm{TU}$, dalteparin $2.5 \mathrm{TU}$, ofloxacin $0.4 \mathrm{~g}$, ciprofloxacin $1 \mathrm{~g}$ oral, $0.5 \mathrm{~g}$ parenteral, norfloxacin $0.8 \mathrm{~g}$, levofloxacin $0.5 \mathrm{~g}$, telmisartan $40 \mathrm{mg}$, amlodipine $5 \mathrm{mg}$, cefpodoxime $0.4 \mathrm{~g}$, paracetamol $3 \mathrm{~g}$, paroxetine $20 \mathrm{mg}$, clonazepam $8 \mathrm{mg}$, aceclofenac $0.2 \mathrm{~g}$, diclofenac $0.1 \mathrm{~g}$,fentanyl $0.6 \mathrm{mg}$,lidocaine $3 \mathrm{~g}$, tranexamic acid $2 \mathrm{~g}$, norethistherone $2.5 \mathrm{~g}$, metoclopramide $30 \mathrm{mg}$, ferrous sulphate $0.2 \mathrm{~g}$, folic acid $0.4 \mathrm{mg}$, progesterone $0.3 \mathrm{~g}$ oral, $5 \mathrm{mg}$ parenteral $0.2 \mathrm{~g}$ rectal,90 mg vaginal, hydroxyl progesterone $10 \mathrm{mg}$, domperidone $0.12 \mathrm{~g}$ rectal, $30 \mathrm{mg}$ parenteral and oral, linezolid $1.2 \mathrm{~g}$, metoprolol $0.15 \mathrm{~g}$, furosemide $40 \mathrm{mg}$, labetalol $0.6 \mathrm{~g}$, cefpodoxime $0.4 \mathrm{~g}$, hydrocortisone $30 \mathrm{mg}$, levosulpiride $0.4 \mathrm{~g}$, cilnidipine $10 \mathrm{mg}$, levothyroxine sodium $0.15 \mathrm{mg}$, budesonide $0.2 \mathrm{mg}$, salbutamol 0.8 $\mathrm{mg}$, a combination of tramadol and paracetamol 4UD[10] i. e-4 tablets per day. W. H. O prescribing indicators were calculated for all the 50 prescriptions in our study, the total number of drugs prescribed were average number of drugs per prescription were 4 , drugs prescribed by generic names were 27, drugs prescribed by essential drug list (EDL) were 48 [11], total number of prescriptions with antibiotics were 49 , drugs prescribed by brand names were 27 , the total number of doses prescribed were 803 .

As per the results, it is quite evident that the postoperative female patients were more than the postoperative male patients. And in the polypharmacy assessment, the prescriptions under the non polypharmacy were considerably high. The defined daily doses of antibiotics were given in the highest doses among all the category of the drugs, almost all the prescriptions contained antibiotic drugs. Postoperative microbial infection is the major cause of the mortality and morbidity. The sole motive of antibacterial drug usage in postoperative patients is to avoid infections and provide prophylaxis. As the sterile surgical procedures could only decrease the risk of contamination but not completely eliminate bacterial infections. Judicious usage of antimicrobial drugs is supremely important as injudicious use can lead to severe adverse effects like the antimicrobial drug resistance. The practice of using antibacterial drugs for prophylaxis has shown to eradicate post-operative infections. By the judicious use of antimicrobial drugs, a notable reduction in the mortality and morbidity rate could be attained. Therefore, the need for antibacterial drug use as prophylaxis is highly accepted.

\section{CONCLUSION}

Our DUR study provides a valuable perception about the comprehensive pattern of drug use in the postoperative patients in the respective departments of surgical gastroenterology, obstetrics, and gynaecology. The study is useful in the analysis of all the drugs used in the postoperative patients. The study of polypharmacy, defined daily doses, W. H. 0 prescribing indicators aids in the optimisation of the drug therapy, it also provides valuable insight to the medical practitioners and the other health care providers regarding the optimisation of the drug therapy. The study regarding the DDD and the antibiotic prophylaxis treatment aids in decreasing the mortality and morbidity rate among the postoperative cases. Ultimately decreases the health care burden in the society. Thus our study concludes that a wide range of antibiotics is utilised to improve the rational use of drugs. Regular and more DUR studies and drug monitoring are recommended to minimize the harmful drug effects and improve drug optimisation. Drug utilization study knowledge will enable healthcare providers to render their services more efficiently.

\section{ACKNOWLEDGMENT}

I would like to express my deep sense of gratitude to my dear Parents and sister. Deep regards and appreciation to Dr. Jwanesh Arnold for initiating the idea of DUR and for all the suggestions made during our work. We have been blessed to have a friendly and helpful team, G. Ramya Sree, Moinuddin Basha, Bhuvana Vanama, Sai Teja. We express our endearments to our team for their help in data collection, support, and constant prayers.

\section{AUTHORS CONTRIBUTIONS}

Dr. Madhuri Devi Thadiboina has made contributions to design, the collection of data and conceptualize the work. Dr. Kanna Vadivel has made a substantial contribution in drafting, analysis and reviewing the article content critically.

\section{CONFLICT OF INTERESTS}

\section{Declared none}

\section{REFERENCES}

1. Kosse RC, Koster ES, Kosse RC, Koster ES, de Vries TW, Bouvy ML. Drug utilisation among dutch adolescents: a pharmacy prescription records study. Arch Dis Child 2018. Doi:10.1136/archdischild-2017-314692

2. Bhandary A, Bhandari PR. Drug usage pattern of antihypertensive drugs in elderly diabetic, hypertensive in-patients with or without impaired renal function in a tertiary care hospital. Int J Basic Clin Pharmacol 2018;7:696-706. 
3. World Health Organization. The selection and use of essential medicines: report of the WHO expert committee, 2015 (including the 19th WHO Model List of Essential Medicines and the 5th WHO Model List of Essential Medicines for Children). World Health Organization; 2015.

4. Wagle l, Thomas AA, Shrestha S. Drug utilization study of stroke and other patients admitted to general ward of neurology unit at quaternary care private hospital. Int J Curr Pharm Res 2017;9:23-8.

5. Stern CS. Medication utilization the great multiplier!. Int J Pharm Practice 2016;24:75-7.

6. Warholak TL, Rupp MT, Zale A, Hines M, Park S. Check it out: a practical tool for improving medication safety. J Am Pharm Assoc 2015;55:621-5.

7. Viswanathan M, Kahwati LC, Golin CE, Blalock SJ, CokerSchwimmer E, Posey R, et al. Medication therapy management interventions in outpatient settings: a systematic review and meta-analysis. JAMA Int Med 2015;175:76-87.

8. Walker R. Clinical pharmacy and therapeutics e-book. $5^{\text {th }}$ ed Elsevier Health Sciences; 2012.

9. Tripathi KD. Essentials of medical pharmacology. $6^{\text {th }}$ ed. JP Medical Ltd; 2013.

10. WHO collaboration centre for drug statistics for drug methodology; 2017. Available from: https://www.whocc.no/ddd/ definition_and_general_considera/logged. [Last accessed on 01 Jul 2018]

11. World Health Organisation. 20 ${ }^{\text {th }}$ Essential medicines and health products; 2017. Available from: http://www.who.int/ medicines/news/2017/20th_essential_med-list/en/logged [Last accessed on 03 Jul 2018] 